\title{
Surgically assisted rapid maxillary expansion - A case report
}

\author{
Expansão rápida da maxila cirurgicamente assistida - Um relato de caso
}

Expansión maxilar rápida asistida quirúrgicamente: Informe de un caso

Nelson Padilha Silva

ORCID: https://orcid.org/0000-0001-7873-5080 São Paulo State University, Brazil E-mail: nelsonpad@gmail.com

Marlice Hayumi Theles Okumura ORCID: https://orcid.org/0000-0002-7595-2650 São Paulo State University, Brazil E-mail: hayumitheles@gmail.com

Luara Teixeira Colombo

ORCID: https://orcid.org/0000-0001-6261-6044 São Paulo State University, Brazil

E-mail: luara_colombo@hotmail.com

Henrique Hadad

ORCID: https://orcid.org/0000-0001-6446-3643 São Paulo State University, Brazil E-mail: henriquehadad@gmail.com

Laís Kawamata De Jesus

ORCID: https://orcid.org/0000-0002-0459-5860 São Paulo State University, Brazil

E-mail: kawamata_lais@hotmail.com

Ana Flávia Piquera Santos

ORCID: https://orcid.org/0000-0001-7562-772X

São Paulo State University, Brazil

E-mail: anaflaviaps_06@hotmail.com

Pier Paolo Poli

ORCID: https://orcid.org/0000-0003-3739-1490

University of Milan, Italy

E-mail: pierpaolo_poli@fastwebnet.it

André Luiz da Silva Fabris

ORCID: https://orcid.org/0000-0002-1777-2125

São Paulo State University, Brazil

E-mail: andre.fabris@hotmail.com

Leonardo Perez Faverani

ORCID: https://orcid.org/0000-0003-2249-3048

São Paulo State University, Brazil

E-mail: leonardo.faverani@unesp.br

Ana Paula Farnezi Bassi

ORCID: https://orcid.org/0000-0002-0031-4953

São Paulo State University, Brazil

E-mail: apfarnezibassi@gmail.com

Alessandra Marcondes Aranega

ORCID: https://orcid.org/0000-0001-5856-7972

São Paulo State University, Brazil

E-mail: alessandra@foa.unesp.br

Osvaldo Magro Filho

ORCID: https://orcid.org/0000-0002-9821-2479 São Paulo State University, Brazil

E-mail: osvaldo.magro@unesp.br

Idelmo Rangel Garcia-Júnior

ORCID: https://orcid.org/0000-0001-8892-781X São Paulo State University, Brazil

E-mail: irgcirurgia@gmail.com

Francisley Ávila Souza

ORCID: https://orcid.org/0000-0002-1427-071X São Paulo State University, Brazil E-mail: francisley.avila@unesp.br 


\begin{abstract}
Surgically assisted rapid maxillary expansion (SARME) is a combination of surgical and orthodontic procedures, indicated for the treatment of true transverse skeletal deficiencies in skeletally mature individuals. The present report presents a clinical case of SARME, performed under local anesthesia, by a multidisciplinary team, in an outpatient setting. The treatment plan began with the placement of a Hyrax type of orthodontic appliance. In the surgical procedure, horizontal and vertical osteotomies were performed, followed by median palatine suture disjunction. Expansion was performed by daily activation of the disjunctor appliance. After disjunction, orthodontic treatment began to align and level the teeth. On conclusion of treatment, effective expansion of the maxillary arch was observed, with correction of maxillary atrophy and anatomofunctional improvement of the stomatognathic system. In view of the result obtained, it was concluded that SARME is an effective multidisciplinary treatment for the correction of transverse deficiencies of the maxilla.
\end{abstract}

Keywords: Palatal expansion technique; Maxillary osteotomy; Orthodontics corrective; Orthodontic appliances fixed; Maxillofacial development.

\title{
Resumo
}

A expansão rápida da maxila cirurgicamente assistida (ERMCA) é uma combinação de procedimentos cirúrgicos e ortodônticos, indicada para o tratamento de verdadeiras deficiências esqueléticas transversais em indivíduos esqueleticamente maduros. O presente relato apresenta um caso clínico de ERMCA, realizado sob anestesia local, por equipe multidisciplinar, em ambiente ambulatorial. O plano de tratamento começou com a colocação de um aparelho ortodôntico tipo Hyrax. No procedimento cirúrgico foram realizadas osteotomias horizontais e verticais, seguidas de disjunção da sutura palatina mediana. A expansão foi realizada pela ativação diária do aparelho disjuntor. Após a disjunção, iniciou-se o tratamento ortodôntico para alinhar e nivelar os dentes. Ao término do tratamento, observou-se expansão efetiva da arcada superior, com correção da atrofia maxilar e melhora anatomofuncional do sistema estomatognático. Diante do resultado obtido, concluiu-se que o ERMCA é um tratamento multidisciplinar eficaz para a correção de deficiências transversais da maxila.

Palavras-chave: Técnica de expansão palatina; Osteotomia maxilar; Ortodontia corretiva; Aparelhos ortodônticos fixos; Desenvolvimento maxilofacial.

\section{Resumen}

La expansión maxilar rápida asistida quirúrgicamente (EMRAQ) es una combinación de procedimientos quirúrgicos y de ortodoncia, indicada para el tratamiento de verdaderas deficiencias esqueléticas transversales en individuos esqueléticamente maduros. El presente informe presenta un caso clínico de EMRAQ, realizado bajo anestesia local, por un equipo multidisciplinario, de forma ambulatoria. El plan de tratamiento comenzó con la colocación de un aparato de ortodoncia tipo Hyrax. En el procedimiento quirúrgico se realizaron osteotomías horizontales y verticales, seguidas de disyunción de la sutura palatina media. La expansión se realizó mediante la activación diaria del dispositivo disyuntor. Después de la disyunción, el tratamiento de ortodoncia comenzó a alinear y nivelar los dientes. Al finalizar el tratamiento, se observó una expansión efectiva del arco maxilar, con corrección de la atrofia maxilar y mejoría anatomofuncional del sistema estomatognático. A la vista del resultado obtenido, se concluyó que EMRAQ es un tratamiento multidisciplinario eficaz para la corrección de deficiencias transversales del maxilar.

Palabras clave: Técnica de expansión palatina; Osteotomía maxilar; Ortodoncia correctiva; Aparatos ortodóncicos fijos; Desarrollo maxillofacial.

\section{Introduction}

Clinically, transverse deficiency of the maxilla is observed in cases presenting a discrepancy between the size of the maxillary and mandibular dental arches, in which the maxilla is atrophic and has considerably smaller dimensions than the mandible, leading to a condition of malocclusion (Betts, et al., 1995). Should the discrepancy be real or skeletal, it is necessary to perform surgically assisted rapid maxillary expansion (SARME) in adult patients because of skeletal maturation (Suri \& Taneja, 2008).

SARME is a combination of orthodontic and surgical procedures, in which an increase in the transverse dimensions of the maxillary dental arch is promoted, in addition to alteration of the position of the alveolar bone processes of the maxillary segments and teeth (Lehman \& Haas, 1989).

The aim of this study was to present a case of surgically assisted rapid maxillary expansion, with the use of a tooth supported expander of the Hyrax type. 


\section{Methodology}

The methodology applied in this study followed the guidelines described in Pereira (2018) and consists of a case report of a 27-year-old male patient, presented to the Buco-Maxillofacial Surgery and Traumatology outpatient clinic of the São Paulo State University (UNESP), School of Dentistry, Araçatuba, referred by an orthodontist to perform a rapid maxillary expansion assisted surgically.

\section{Case Report}

A 27-year-old Caucasian man, presented to the authors, referred by the orthodontist to have SARME performed. Careful anamnesis was collected and routine laboratory exams requested, in which it was found that the patient presented ASA Grade I surgical risk. During clinical evaluation, transverse deficiency of the maxilla with posterior cross bite was observed (Figure 1). Radiographically, root divergence was observed of teeth 11 and 21, with sufficient space for median osteotomy (Figure 2).

Figure 1. Frontal view of the clinical situation before starting the treatment.

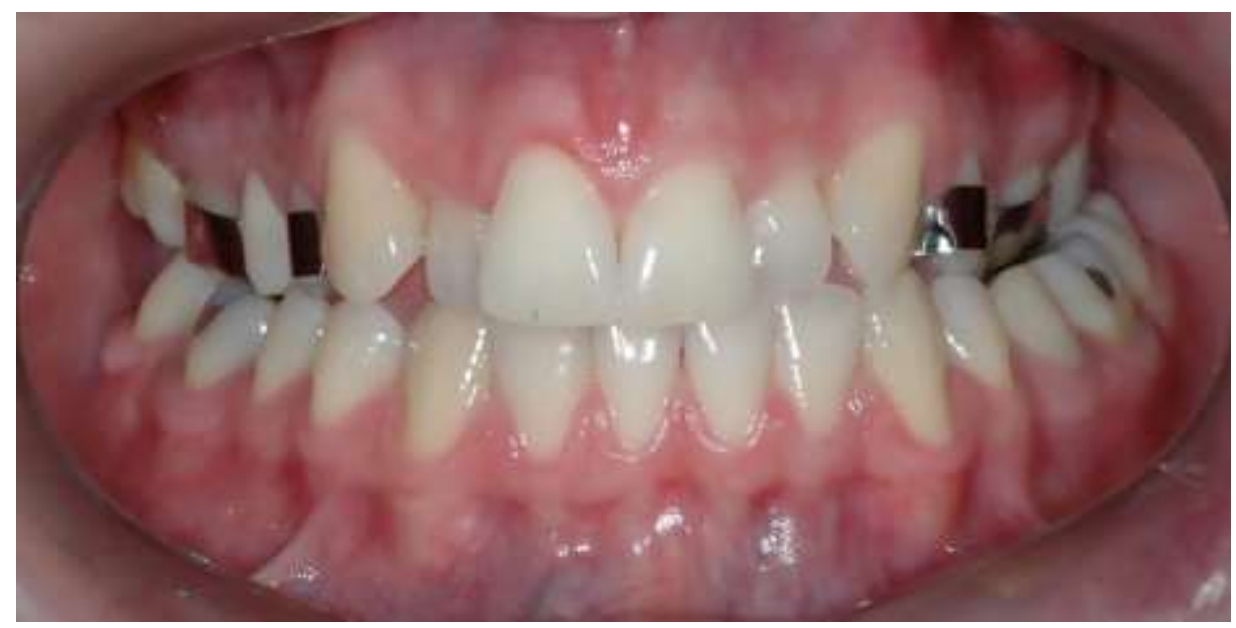

Source: Own authorship.

Figure 2. Pre-operative orthopantomograph.

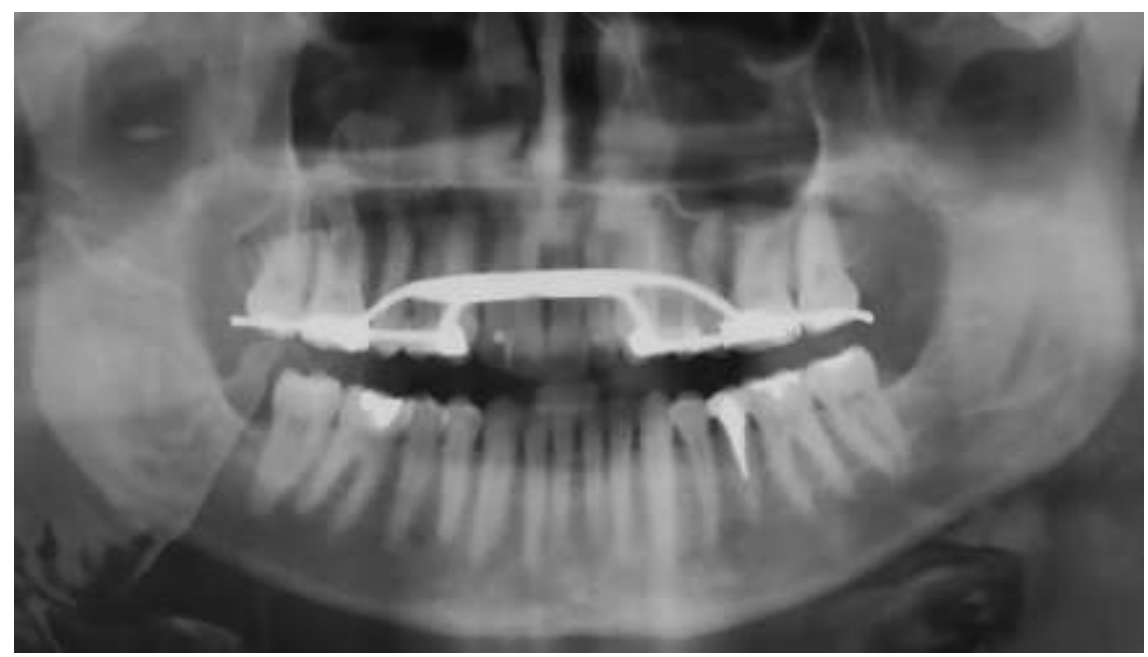

Source: Own authorship. 
Fifteen days before the surgery, the orthodontist cemented the Hyrax type expander appliance to the first premolars and first molars, using resin-reinforced glass ionomer cement to allow patient to adapt to it (Fuji-Ortho LC, GC America Inc, Tokyo, Japan) (Figure 3).

Figure 3. Clinical view of the Hyrax-type palatal expander in position.

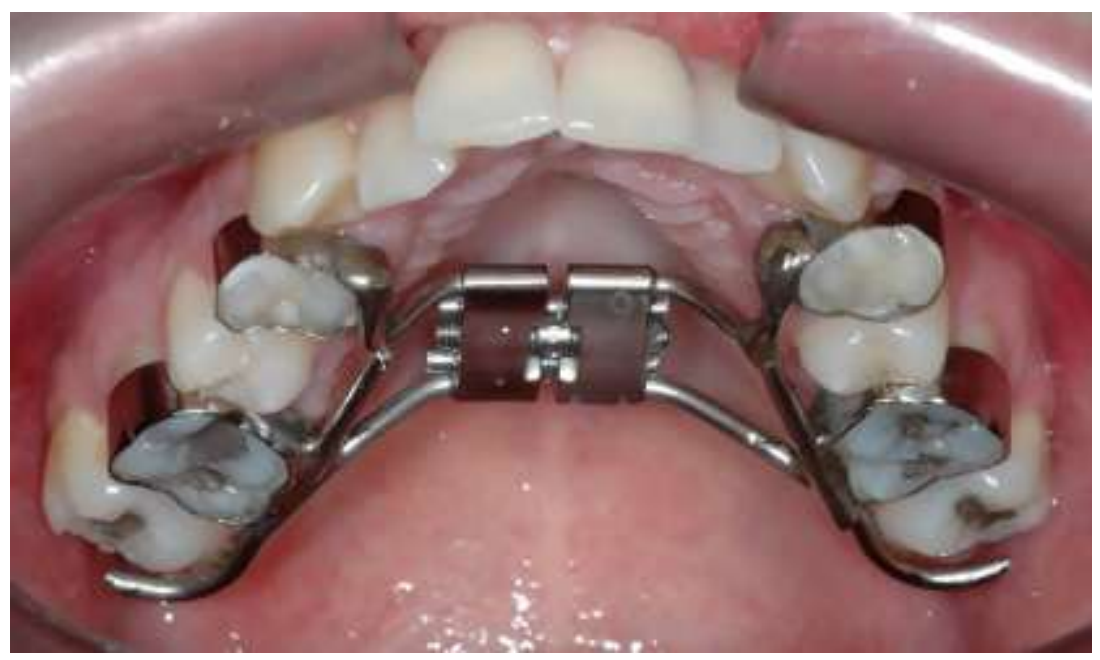

Source: Own authorship.

The patient was given a prescription for $4 \mathrm{mg}$ of Amoxicillin (Amoxil, GSK, Rio de Janeiro, Brazil), 2mg of Betamethasone (Celestone, Mantecorp Quim, Rio de Janeiro, Brazil) and 7.5 mg of Midazolan (Dormonid, Roche, Rio de Janeiro, Brazil). Surgery began with intra-oral antisepsis with a 0.12\% Chlorhexidine Digluconate solution (Periogard, Colgate-Palmolive Company, Osasco, Brazil) followed by extra-oral degerming and antisepsis with a 10\% PVPI degerming and topical solution (PVP-I 10\%, Riodeine, Rioquímica, São José do Rio Preto, Brazil) followed by apposition of the sterile fields. The surgery was performed in an outpatient basis, under local anesthesia by infiltrations of 2\% Mepivacaine Chloride solution (adrenalin 1:100.000, DFL, Rio de Janeiro, Brazil).

The surgical technique began with a bilateral mucoperiosteal horizontal incision, made in the depth of the vestibule, approximately $3 \mathrm{~mm}$ above the mucogingival junction, extending from the canine to the first molar region, using a No.15 scalpel blade. The mucoperiosteal flap was detached, exposing the lateral portion of the nasal fossa and pyriform aperture, as well as the region of the pterygoid and maxillary tuber processes (Figure 4A). The maxillary horizontal osteotomy based on the Le Fort I type, began respecting 4 to $5 \mathrm{~mm}$ above the apices of the teeth, and ran parallel to the occlusal line, starting from the lateral portion of the pyriform aperture through to the region of the maxillary tuber, bilaterally. These procedures were performed with burs 701 and 702 (KG Sorensen, São Paulo, Brazil) coupled to a straight handpiece (Kavo, Joinvile, Brazil) mounted on an electric motor (Kavo, Joinvile, Brazil), under constant irrigation with $0.9 \%$ physiological solution (Darrow, Rio de Janeiro, Brazil) (Figure 4B). The pillars of strength were completely sectioned, starting with the canine pillar followed by the zygomatic pillar. Bilaterally, the pterygoid process was separated from the maxilla by means of an $8 \mathrm{~mm}$ Wagner curved chisel (Figure 4C). After the horizontal osteotomies, a V-shaped incision was made in the region of the superior labial frenum, followed by detachment and exposure of the anterior nasal spine up to the alveolar bone crest between teeth 11 and 21 (Figure 4D). A vertical osteotomy was performed, which went from the anterior nasal spine up to close to the alveolar crest, using bur 701 (KG Sorensen, São Paulo, Brazil). The intermaxillary region was initially separated by means of a delicate straight 3 mm West chisel with the purpose of making the pathway for the Sverzut palatine disjunction chisel, respecting the roots of the central incisors (Figure 4E). Entry of the Sverzut chisel was deepened up to the palatine bone, while the surgeon's index finger 
was placed over the incisor papilla in order to feel the passage of the chisel as it separated the palatine suture (Figure 4F). At this stage, the disjunctor appliance was activated in order to observe the release and symmetry of the sutures during expansion, and it was deactivated immediately after confirmation of this (Figure 4G). After irrigation and cleaning of the osteotomies with 0.9\% physiological solution (Darrow, Rio de Janeiro, Brazil) a scalloped continuous suture was performed bilaterally with 4-0 Polyglactin 910 (Vicryl 4.0, Ethicon, Johnson, São José dos Campos, Brazil) reinforced with simple sutures with 5-0 nylon (Ethicon, Johnson, São José dos Campos, Brazil) followed by the suture in the midline (Figure 4H). The post-operative medication consisted of $500 \mathrm{mg}$ Amoxicillin (Amoxil, GSK, Rio de Janeiro, Brazil) administered orally, every 8 hours, for 7 days, 100 mg Nimesulide (Nisulide, Aché Lab Pharm, São Paulo, Brazil) administered orally, every 12 hours, for 3 days, and analgesia with $500 \mathrm{mg}$ Sodium Dipyrone (Novalgina, Sanofi-Aventis Pharm, São Paulo, Brazil) administered orally, every 4 hours in case of pain, whenever necessary. The patient was recommended to take post-operative care and maintain correct oral hygiene, complemented by chemical control of bacterial plaque, by means of moderate topical mouth washes with $0.12 \%$ Chlorhexidine Digluconate (Periogard, Colgate-Palmolive Company, Osasco, Brazil) twice a day for 14 days up to suture removal (Figure 5). In addition, the patient was kept on a soft diet for 60 days post-operatively.

Figure 4. A: Exposure of the surgical area in the right maxilla after the detachment of the mucoperiosteal flap; B: Maxillary osteotomy line starting from the lateral portion of the pyriform aperture through to the region of the maxillary tuber; $\mathrm{C}$ : Separation of the pterigoyd process from the right emi-maxilla; D: Exposure of the anterior nasal spine up to the alveolar bone crest; E: Initial separation of the premaxillary region; F: Separation of the palatine suture controlled by the surgeon's finger. The resultant upper central inter-incisor diastema is clearly recognisable; G: Assessment of the release and symmetry of the sutures by activation of the disjunctor appliance; H: Post-operative view of the suture.
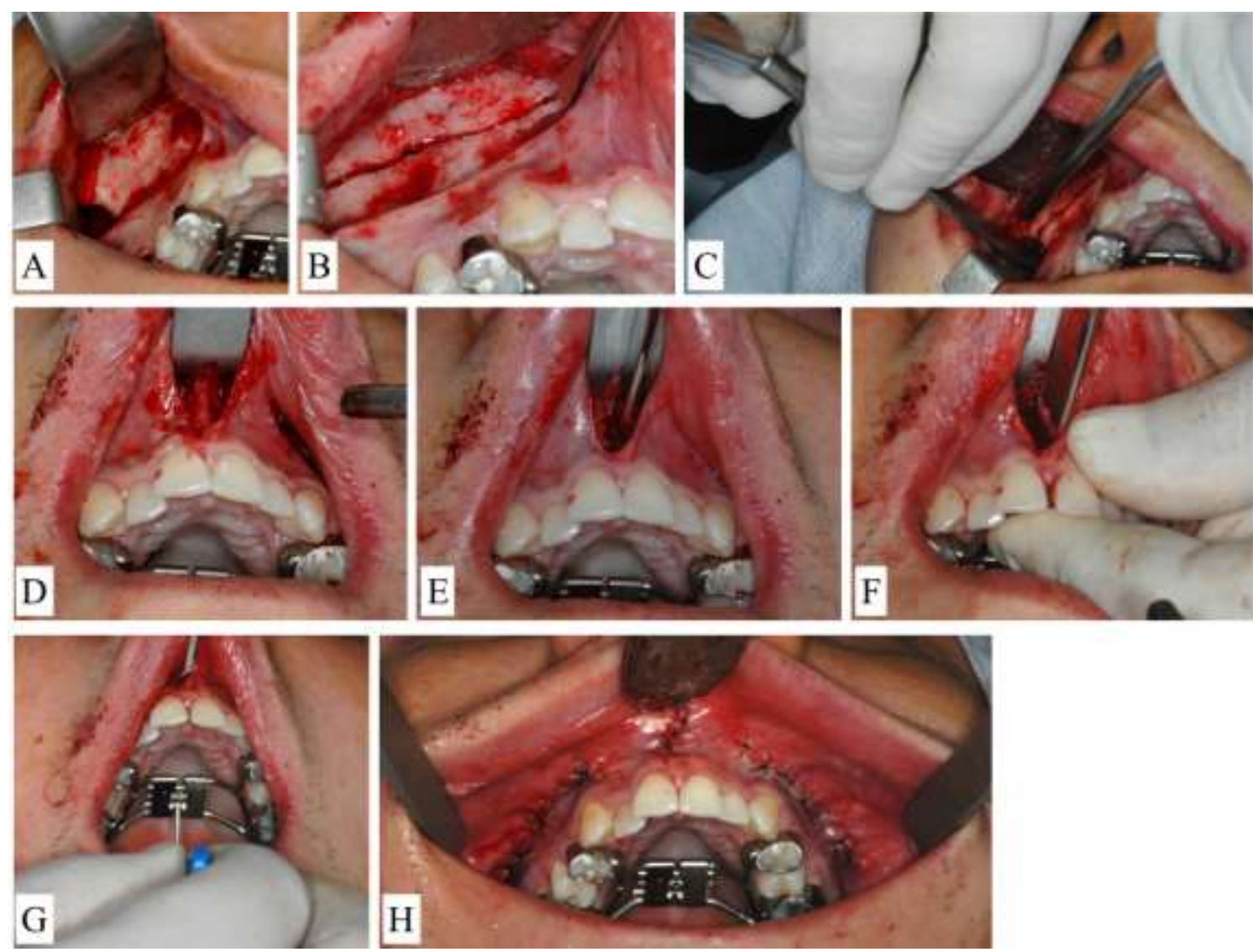

Source: Own authorship. 
Figure 5. Clinical view 14 days after the surgery. It is possible to observe the interincisor diastema after 7 days from the beginning of the treatment. A transverse gain of $3.5 \mathrm{~mm}$ has been obtained.

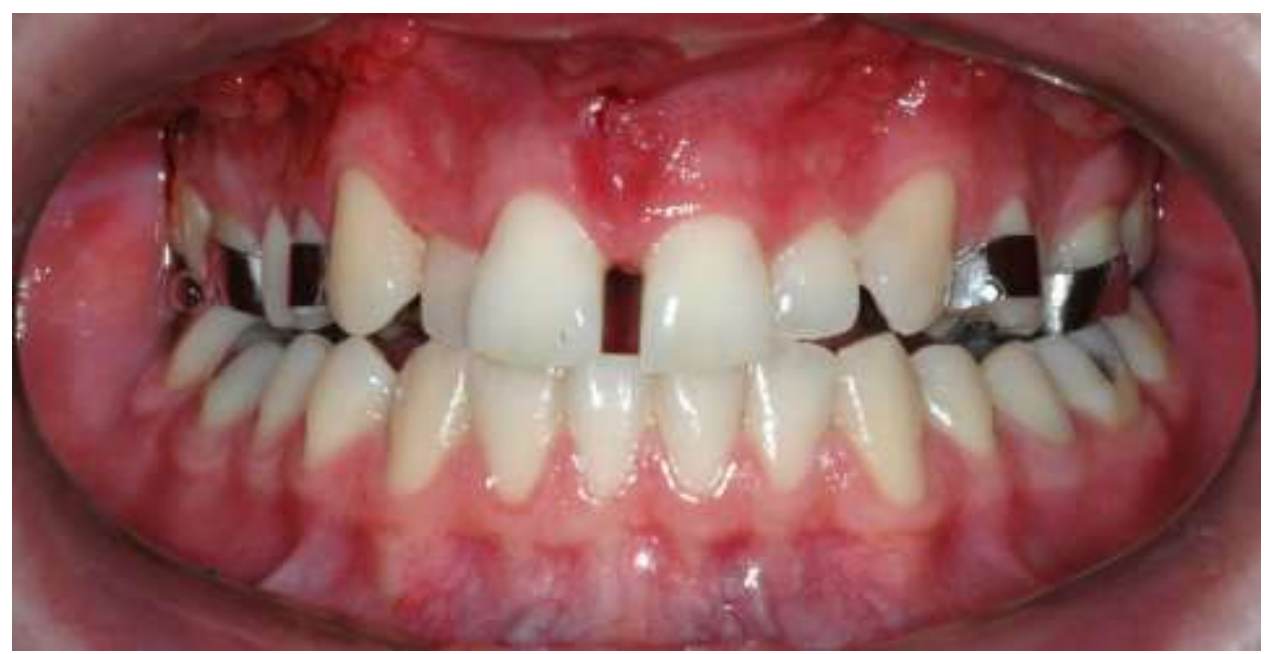

Source: Own authorship.

Activation of the Hyrax appliance was done by the patient under the orthodontist's guidance, starting on the seventh post-operative day, being $1 / 4$ of a turn $(0.25 \mathrm{~mm})$, twice daily, until complete expansion was achieved (Figure 6). Thus, after reaching the desired patient expansion, the device is locked, and the patient remains for another 4 months with this device. So, after expansion, the orthodontic treatment began to align and level the teeth (Figure 7).

Figure 6. Intra-oral radiograph obtained at the end of the palatal expansion after 15 days from the beginning of the treatment.

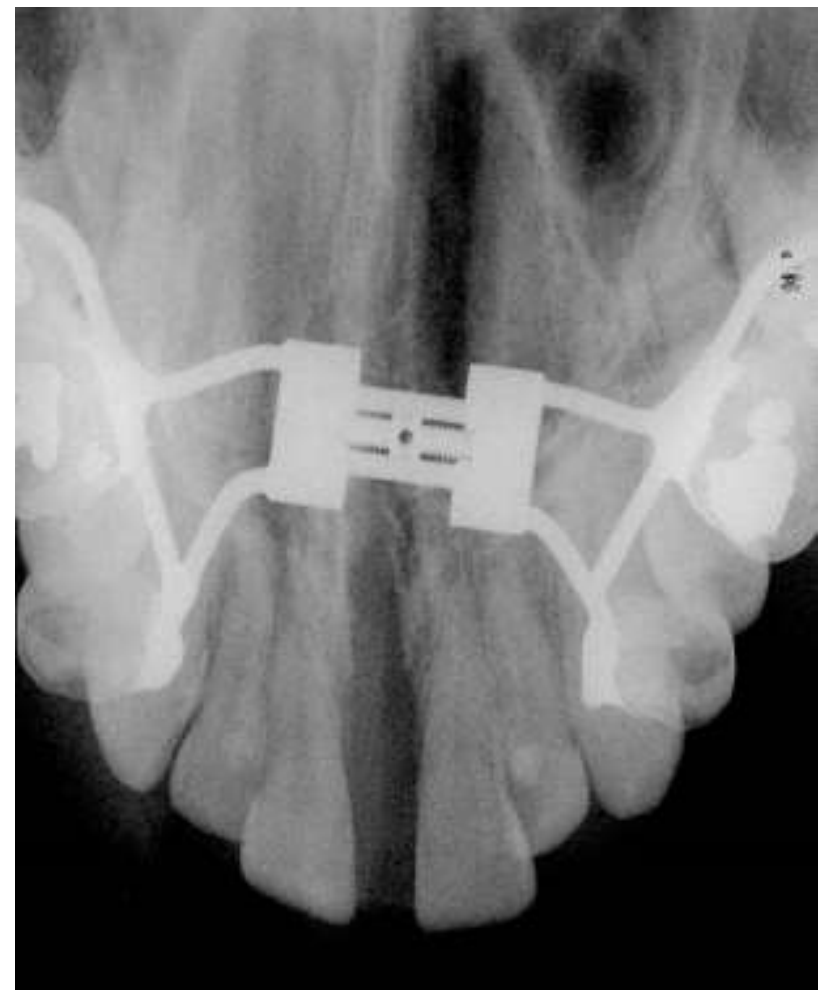

Source: Own authorship. 
Figure 7. Clinical result at the end of the orthodontic treatment.

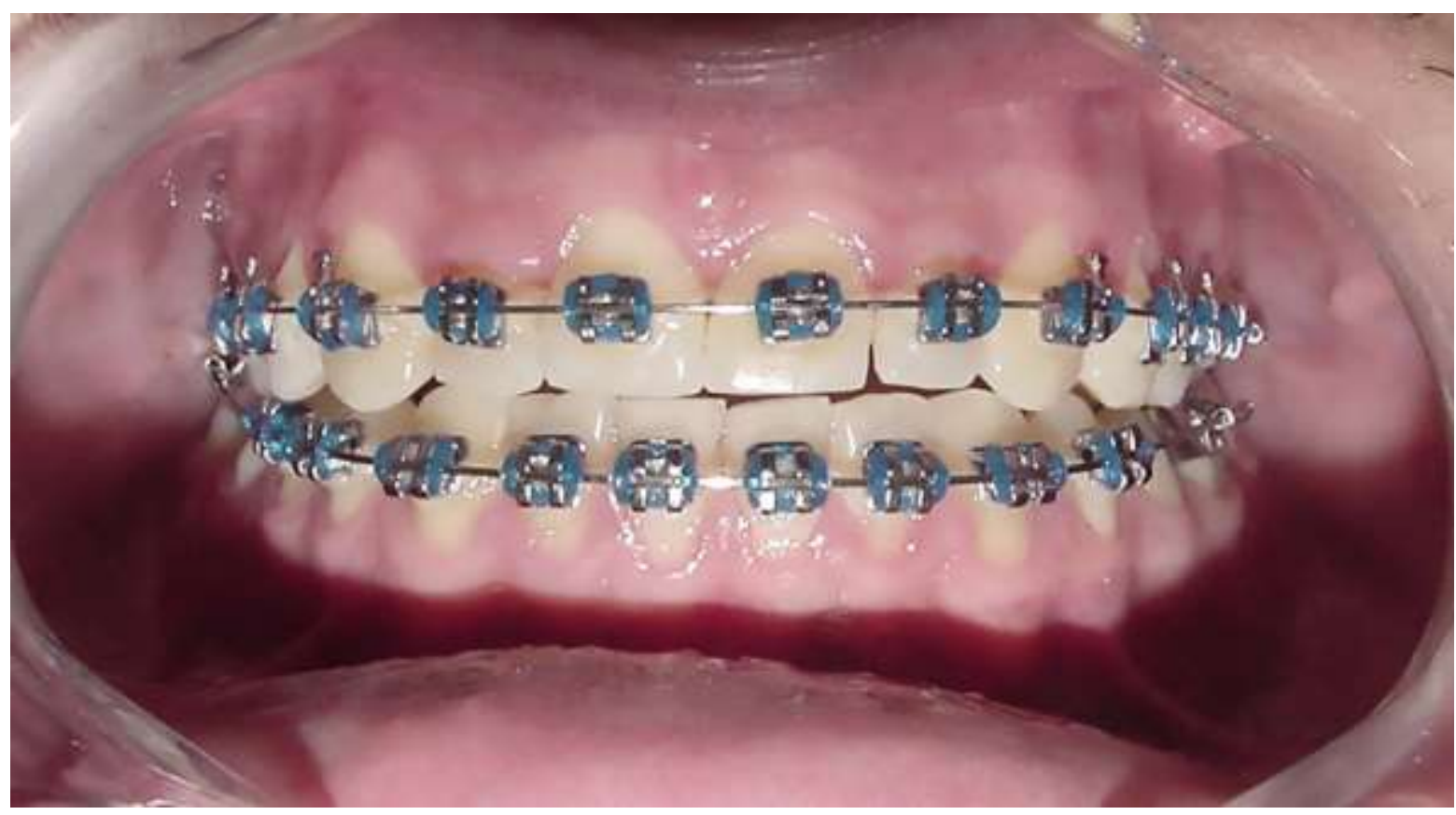

Source: Own authorship.

\section{Discussion}

Surgical and orthodontic treatment of real transverse and anteroposterior deficiencies by means of SARME represents an adequate therapeutic conduct for the correction of maxillary atresia and occlusal deviations in adult patients, irrespective of the occlusal stage. It is also indicated for patients with transverse discrepancy of the maxilla $\geq 5 \mathrm{~mm}$, correction of occlusal deviations, cases of palatal expansion, uni- or bi-lateral transverse hypoplasia of the maxilla, increase of space in the dental arch, or in cases of orthodontic failures due to resistance of the sutures (Koudstaal, et al., 2005). It has the advantages of improving the anatomy and function of the respiratory airways, increase in the oral cavity providing extra space for function of the tongue, improvement in phonation and mastication, high stability of the result obtained, elimination of the buccal corridor (dark space), periodontal health, minimal morbidity and discomfort during the expansion process, in addition to avoiding tooth extractions for alignment of the arch (Lagravere, et al., 2006).

For the correct diagnosis of transverse discrepancy, manipulation of the plaster models in association with clinical evaluation and analysis of maxillary occlusal radiographs and profile teleradiographs becomes essential. Incorrect planning may lead to unnecessary maxillary expansion or anterior inclination of the maxillary teeth. In this clinical case, this entire planning was previously performed by the orthodontist and oral and maxillofacial surgeon. Due to the patient's age, a rapid maxillary expansion without surgical assistance would not have been sufficient.

The techniques currently available differ between the number of osteotomy in areas resistant to expansion, namely the pyriform aperture, zygomatic pillar, median palatine suture and pterygoid junction (Koudstaal, et al., 2005). For their separation, horizontal Le Fort I subtotal osteotomy and vertical osteotomy of the intermaxillary suture are necessary, which involve complete release of all the articulations of the maxilla.

Conservative techniques that do not encompass osteotomy of the intermaxillary suture and pterygoid processes may result in failures during activation of the tooth-supported appliance, discomfort to the patient, in addition to favouring notable relapses due to insufficient expansion, inevitably leading to a second surgical procedure (Chamberland \& Proffit, 2011). Other techniques that involve the separation of the median palatine suture, with direct access to the palatine bone have been related as 
possible causes of complications, such as necrosis of the palate by the post-surgical placement of the tooth-supported appliance, injury to the major palatine nerve, in addition to vascular sequelae. In this study, the technique used was the horizontal Le Fort I subtotal osteotomy and vertical osteotomy of the intermaxillary suture with the purpose of providing a more effective expansion.

In order to avoid possible complications, the ideal disjunctor appliance must be as resistant as possible, in addition to having tooth-supported anchorage to maximize the orthopaedic effects and allow good vascularization in the adjacent tissues. Other appliances for surgically assisted maxillary disjunction have been mentioned in the literature as essentially osteosupported distractor appliances. In this specific clinical case the disjunctor used was the Hyrax appliance because it has all the above-mentioned characteristics, in addition to be the most feasible. The Hyrax type of disjunctor present high stability, practicality and rigidity, less probability of irritation, and is easy to clean; it allows ample surgical access, in addition to avoiding necrosis in the palate as it does not compress the tissues (Gunyuz Toklu, et al., 2015).

The Hyrax type of disjunctor appliance must be placed by the orthodontist by means of cementation before the surgery is performed. Among the possible materials used for cementing the orthodontic bands, is zinc phosphate cement, and the conventional type of glass ionomer cement, reinforced with metal or with resin, with the resin-reinforced type being most effective in bond strength tests, resistance to erosion and shear tests. For such reasons, in this specific case, the bands of the expander appliance were cemented with a resin-reinforced glass ionomer cement.

Some drawbacks related to SARME have been reported, including post-operative pain and oedema, debonding and loosening of orthodontic bands, root resorption, soft tissue lesion, bucco-nasal fistulas, tooth inclinations and bone fenestration. Other rarer intercurrences, such as amaurosis due to lesion of the optic nerve and intra-ocular oedema have been related (Cakarer, et al., 2017). Thus, the identification of individual risk factors that may predispose patients to adverse outcomes is imperative (Williams, et al., 2012). During the surgical and orthodontic stages in this clinical case, no complications or intercurrences were found.

Among the advantages presented by SARME, the increase in transverse dimension with gain of bone mass after surgical treatment is pointed out, in addition to improvement in nose breathing, stability and predictability of the result, and elimination of the buccal corridor dark space (Koudstaal, et al., 2005). An improvement in the level of hearing (audition) has also been reported (Villano, et al., 2006).

In general, SARME may be considered a low risk procedure, however the literature demonstrates some complications (Koudstaal, et al., 2005). Results found in the literature suggest that this procedure can be safely performed under local anestesia (Laino, et al., 2016). In less severe cases, where there is no need to completely release the zygomaticomaxillary junction, that is, just performing an osteotomy in the zygomatic buttress, a local anesthesia is well indicated. So, in more complicated cases such as severe maxillary atrophy, general anesthesia should be considered to allow complete corticotomy and release in the zygomaticomaxillary junction.

It can be admitted that the SARME represents an effective therapy for the correction of transverse deficiencies of the maxilla and occlusal deficiencies. Therefore, the choice of the ideal procedure must be related to the patient's age and consequently the stage of calcification of the sutures.

\section{Conclusion}

The rapid expansion of the surgically assisted maxilla, reported in this clinical case, proved to be an effective, safe and well-regarded procedure for the correction of transverse deficiency in adult patients or those who were not successful in orthodontic treatment, being of low mobility, constituting effective multidisciplinary treatment to correct transverse maxillary deficiencies. However, the discrepancy may be masked by sagittal deformities. Physical and radiographic examination, in 
addition to model analysis, are fundamental for the elaboration of the treatment plan. So, even knowing the effectiveness of SARME, there are discussions in the literature about the ideal age for performing the surgical process.

\section{References}

Betts, N. J., Vanarsdall, R. L., Barber, H. D., Higgins-Barber, K., \& Fonseca, R. J. (1995). Diagnosis and treatment of transverse maxillary deficiency. The International journal of adult orthodontics and orthognathic surgery, 10(2), 75-96.

Chamberland, S. \& Proffit, W. R. (2011). Short-term and long-term stability of surgically assisted rapid palatal expansion revisited. American journal of orthodontics and dentofacial orthopedics, 139(6), 815-822.

Cakarer, S., Keskin, B., Isler, S. C., Cansiz, E., Uzun, A., \& Keskin, C. (2017). Complications associated with surgically assisted rapid palatal expansion without pterygomaxillary separation. Journal of stomatology, oral and maxillofacial surgery, 118(5), 279-282.

Gunyuz Toklu, M., Germec-Cakan, D., \& Tozlu, M. (2015). Periodontal, dentoalveolar, and skeletal effects of tooth-borne and tooth-bone-borne expansion appliances. American journal of orthodontics and dentofacial orthopedics, 148 (1), 97-109.

Koudstaal, M. J., Poort, L. J., Van der Wal, K. G. H., Wolvius, E. B., Prahl-Andersen, B., \& Schulten, A. J. M. (2005). Surgically assisted rapid maxillary expansion (SARME): a review of the literature. International journal of oral and maxillofacial surgery, 34(7), 709-714.

Lagravere, M. O., Major, P. W., \& Flores-Mir, C. (2006). Dental and skeletal changes following surgically assisted rapid maxillary expansion. International journal of oral and maxillofacial surgery, 35(6), 481-487.

Laino, L., Troiano, G., Dioguardi, M., Perillo, L., Laino, G., Muzio, L. L., \& Cicciù, M. (2016). Patient discomfort during and after surgically assisted rapid maxillary expansion under local anaesthesia. The Journal of craniofacial surgery, 27(3), 772-775.

Lehman Jr, J. A., \& Haas, A. J. (1989). Surgical-orthodontic correction of transverse maxillary deficiency. Clinics in plastic surgery, 16(4), 749-755.

Pereira, A.S., Shitsuka, D. M, Parreira, F. J. \& Shitsuka, R. (2018). Metodologia da pesquisa científica. UFSM.

Suri, L., \& Taneja, P. (2008). Surgically assisted rapid palatal expansion: a literature review. American journal of orthodontics and dentofacial orthopedics, $133(2), 290-302$.

Villano, A., Grampi, B., Fiorentini, R., \& Gandini, P. (2006). Correlations between rapid maxillary expansion (RME) and the auditory apparatus. The Angle orthodontist, 76(5), 752-758.

Williams, B. J., Currimbhoy, S., Silva, A., \& O'Ryan, F. S. (2012). Complications following surgically assisted rapid palatal expansion: a retrospective cohort study. Journal of oral and maxillofacial surgery, 70(10), 2394-2402. 